\title{
Pelatihan Penggunaan Microsoft Teams pada Mahasiswa Baru
}

\author{
Joosten', Heru Kurniawan², Sherly Joe ${ }^{3}$ \\ 1Prodi Sistem Informasi Universitas Mikroskil (d.h STMIK Mikroskil) \\ e-mail: joosten.ng@mikroskil.ac.id \\ 2Prodi Teknik Informatika Universitas Mikroskil (d.h STMIK Mikroskil) \\ e-mail:heru.kurniawan@mikroskil.ac.id \\ 3Prodi Manajemen Universitas Mikroskil (d.h STIE Mikroskil) \\ e-mail: sherly_juu@mikroskil.ac.id
}

\begin{abstract}
Abstrak
Sebelum masa pandemi, para pelajar bisa mendatangi sekolah/kampus dan belajar di dalam kelas yang diajarkan langsung oleh guru. Tetapi pada saat pandemi COVID-19 melanda di berbagai negara termasuk Indonesia, para pelajar harus bersekolah atau kuliah di rumah atau sekarang lebih dikenal belajar daring. Para pelajar terkadang menggunakan aplikasi yang terkadang kurang membantu mereka dalam melakukan pembelajaran daring. Seperti sinyal tidak kuat, aplikasi tidak cocok dengan spesifikasi perangkat, dan masih banyak lainnya. Para pelajar sering kesulitan berdiskusi atau bertanya lebih lama pada saat pembelajaran masa kini. Para pelajar yang mendaftar jadi mahasiswa baru di Universitas Mikroskil dihadapkan penggunaan aplikasi Ms. Teams yang belum pernah mereka gunakan selama SMA. Dari permasalahan tersebut, diperlukan pengenalan dan pelatihan menggunakan Ms. Teams dalam pembelajaran masa kini agar suasana belajar menjadi aktif dan menyenangkan.
\end{abstract}

Kata Kunci: pembelajaran masa kini, Ms. Teams, pandemi COVID-19

\begin{abstract}
Before the pandemic, students could go to schools/campuses and study in classes taught directly by teachers. But when the COVID-19 pandemic hit in various countries including Indonesia, students had to go to school or study at home or now better known as online learning. Students sometimes use applications which sometimes do not help them in doing online learning. Such as weak signal, application does not match device specifications, and many others. Students often find it difficult to discuss or ask longer questions during today's learning. Students who register as new students at Mikroskil University are faced with using the Ms. Teams they hadn't used during high school. From these problems, it is necessary to introduce and train using Ms. Teams in today's learning so that the learning atmosphere becomes active and fun.
\end{abstract}

Keywords: modern learning, Ms. Teams, COVID-19 pandemic

\section{Pendahuluan}

Dalam masa kini, perkembangan teknologi cukup pesat dibanding tahun-tahun sebelumnya. Perkembangan teknologi menyebabkan adanya potensi dalam semua 
bidang khususnya dalam bidang pendidikan yang harus direspon secara positif dan adaptif dalam menjawab tantangan yang penuh kompleksitas masa kini (Anaelka, 2018; Fitrisyani et al., 2020). Sebelum adanya pandemi COVID-19, para pelajar bisa mendatangi sekolah untuk belajar dan diajarkan pengajar secara langsung. Pembelajaran merupakan proses transfer ilmu pengetahuan ke dalam skemata pelajar (Syarifudin, 2020). Proses pembelajaran yang dilakukan antara pelajar dengan pengajar tidak terlepas dari beberapa tahapan seperti perencanaan, pelaksanaan, dan evaluasi yang dilakukan oleh pengajar (Syarifudin, 2020). Tahapan pembelajaran tersebut tidak akan berhasil jika tidak dijalankan secara berkesinambungan (Santika, 2020).

Awal bulan Maret 2020, semua negara telah terinfeksi oleh virus COVID-19, termasuk Indonesia (Rigianti, 2020; Wahyono et al., 2020) sehingga WHO menetapkan virus tersebut sebagai pandemi (Sohrabi et al., 2020). Pandemi COVID19 mempengaruhi hampir seluruh bidang, salah satunya adalah bidang pendidikan (Anderson, 2020; Wahyono et al., 2020) sehingga peran dari bidang pendidikan ini sangat penting dan vital (Wahyono et al., 2020; Yang et al., 2019). Pendidikan merupakan suatu usaha yang disadari dan terencana untuk mewujudkan suasana belajar yang aktif dan menyenangkan (Santika, 2020). Penggunaan teknologi dalam dunia pendidikan telah menjadi isu yang sagat penting dan sering dibicarakan dalam berbagai kegiatan (Orgaz et al., 2018; Traxler, 2018), terutama disaat dilaksankannya kebijakan-kebijakan untuk mengurangi angka penyebaran COVID19 saat ini. Seperti yang disebutkan dalam Surat Edaran Tahun 2020 dari Menteri Pendidikan dan Kebudayaan Republik Indonesia pada tangga 24 Maret 2020 Tentang Pelaksanaan Kebijakan Pendidikan Dalam Masa Darurat Penyebaran COVID, dalam Surat Edaran tersebut dijelaskan bahwa proses belajar dilaksanakan di rumah melalui pembelajaran daring/jarak jauh untuk memberikan pengalaman belajar yang bermakna bagi pelajar.

Seorang pengajar baik guru ataupun dosen dituntut tidak hanya ahli menyampaikan materi secara luring, tetapi juga harus bisa menyampaikan materi secara daring (Jamaluddin et al., 2020). Interaksi antara guru dan siswa merupakan salah satu faktor yang sangat berpengaruh terhadap keberhasilan proses belajar-mengajar. Siswa dapat berinteraksi dengan guru menggunakan beberapa aplikasi seperti Classroom, video conference, telepon atau live chat maupun melalui Whatsapp group. Tuntutan pemahaman terhadap berbagai aplikasi ini juga semakin tinggi mengingat dibutuhkannya sebuah aplikasi atau sistem yang mampu mendukung penjadwalan, pemberian materi, serah terima tugas, sarana ujian, diskusi dan lain sebagainya secara lebih terstruktur untuk menciptakan lingkungan belajar yang baik.

Tuntutan tersebut menyebabkan pelajar mengalami kesusahan dalam penerimaan pelajaran dalam masa pandemi ini. Banyak pelajar yang mengeluhkan masalah yang dihadapi selama pembelajaran masa kini. Seperti perangkat yang dipakai. Pelajar mengeluhkan perangkat yang dipakai kurang kompeten dalam memberikan pelajaran secara penuh dikarenakan waktu akses hanya sebentar. Selain itu, masalah jaringan dan koneksi juga menyebabkan pelajar sulit mendengarkan apa yang 
disampaikan oleh pengajar, seperti suara putus-putus yang didengarkan pelajar maupun pengajar (Santika, 2020).

\section{Metode}

Dari permasalahan yang ditemukan, maka solusi yang ditawarkan adalah mengenalkan aplikasi Ms. Teams kepada peserta. Peserta diberikan informasi mengenai aplikasi Ms. Teams dan cara menggunakannnya. Diharapkan dengan pelatihan ini, peserta dapat menggunakan Ms. Teams sebaik mungkin sehingga pembelajaran daring semakin asyik dan tidak membosankan.

Kegiatan pelatihan ini dilaksanakan secara online yang dibagi menjadi dua hari dengan 2 tahapan yaitu Pelatihan Online Learning With Mikroskil dan Have Fun with Online Learning. Pada pelatihan Online Learning With Mikroskil, peserta dikenalkan aplikasi yang ada pada Ms. Teams seperti Activity, Chat, dan lain sebagainya. Dilanjutkan dengan pelatihan cara mengganti foto profil, cara membuat postingan di Teams, cara me-reply postingan orang, memberikan stiker, giphy, atau emoticon, cara meng-upload sebuah file di postingan, dan bahkan me-mention orang yang kita jawab. Setelah itu peserta diajarkan cara melihat tugas, mengumpulkan tugas, mengembalikan tugas jika terdapat kesalahan, dan melihat nilai tugas/kuis yang diberikan oleh pengajar.

Pada pelatihan ke 2, peserta diajarkan cara gabung dalam meeting, mengganti background, mematikan microphone dan kamera video, melakukan share content, memulai dan menghentikan recording, hingga pemanfaatan calendar dalam meeting. Setelah itu dilanjutkan pelatihan cara memanfaatkan Ms. Office secara online, Outlook, Onedrive untuk penyimpanan, dan Ms. Stream untuk video yang di-upload.

Pelaksanaan pengabdian ini dilaksanakan pada tanggal 15 September 2021 dan 17 September 2021 dimulai dari jam 19.00 WIB sampai 21.00 WIB. Sebelum pengabdian dilaksanakan, para pelaksana atau pengajar diberi pelatihan pembekalan penggunaan tools pembelajaran elektronik (ToT Content) berupa apa saja yang perlu diajarkan dan disampaikan ke peserta. Peserta yang dituju adalah mahasiswa baru yang sudah mendaftar ulang di Universitas Mikroskil (d.h STMIK - STIE Mikroskil).

Alasan memilih mahasiswa baru sebagai objek kegiatan dikarenakan selama sekolah SMA, mereka melakukan pembelajaran daring hanya menggunakan aplikasi Zoom dan dibantu dengan Google Classroom untuk meng-upload tugas ataupun ujian. Semenjak pandemi COVID-19, Universitas Mikroskil telah menggunakan Ms. Teams sebagai aplikasi untuk melakukan pembelajaran daring. Para mahasiswa baru akan kebingungan dalam penggunaan aplikasi Ms. Teams sehingga perlu diberikan pelatihan kepada mereka.

Tahapan yang dilaksanakan pada pengabdian ini:

1. Tim pelaksana menganalisis situasi mahasiswa baru selama pembelajaran daring di masa pandemi 
2. Setelah mengetahui kondisi mahasiswa baru, tim pelaksana menanyakan apa keluhan yang dialami oleh mahasiswa baru, seperti aplikasi yang digunakan, perangkat yang ada, sinyal internet.

3. Tim Pelaksana kemudian membuat materi pelatihan yang akan diajarkan ke mahasiswa baru.

4. Tim pelaksana memberikan pelatihan selama 2 hari untuk mengajarkan aplikasi yang digunakan pada saat tahun ajaran baru.

5. Tim pelaksana memberikan pre-test dan post-test kepada mahasiswa baru sekaligus quiz untuk dijawab berdasarkan pelatihan yang diberikan.

6. Tim pelaksana merekap hasil pengisian kuesioner pre-test dengan post-test.

\section{Hasil dan Pembahasan}

Pada awal pelatihan, para mahasiswa baru diberikan beberapa soal pre-test yang ditunjukkan pada Gambar 1.

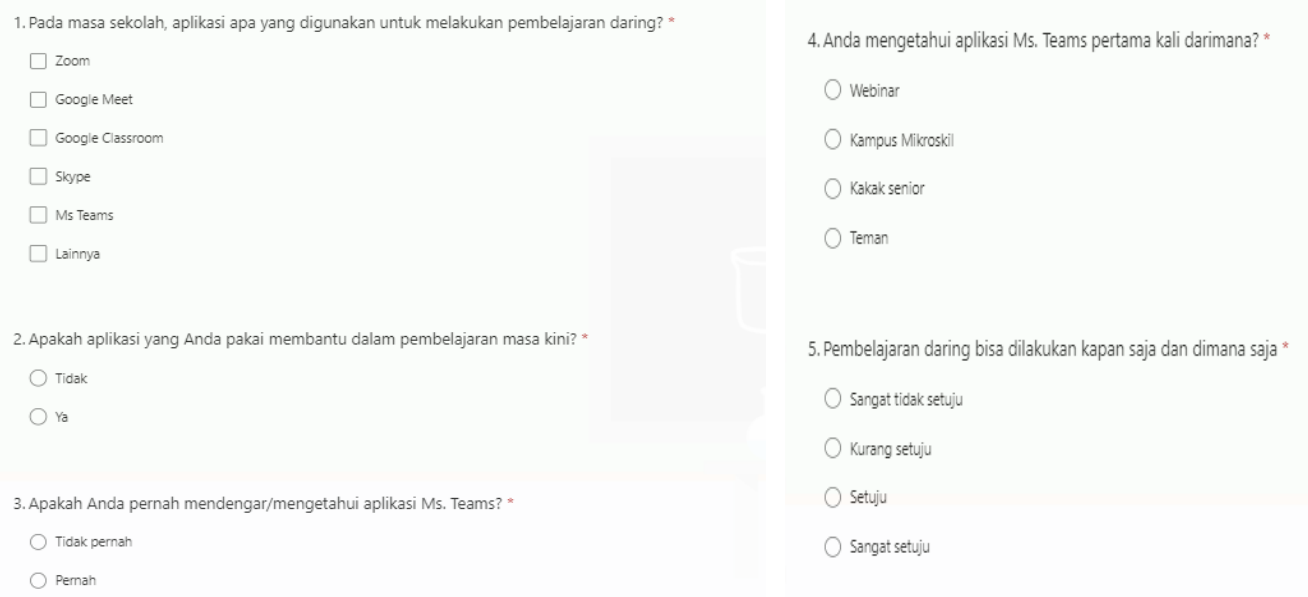

Gambar 1 Soal Pre-Test

Lima soal yang diberikan pada pre-test meliputi seperti aplikasi apa yang pernah dipakai selama sekolah, apakah aplikasi yang dipakai membantu pembelajaran masa kini, apakah pernah mendengar aplikasi Ms. Teams dan asal tahu aplikasi tersebut, serta persetujuan pembelajaran daring bisa dilakukan dimana saja dan kapan saja.

Jumlah mahasiswa baru yang mengikuti pelatihan pada awal berjumlah 40 orang dengan 3 orang pengajar. Pada pelatihan pertama, sejumlah 38 orang menghadiri pelatihan pertama. Dari 38 orang yang mengisi pre-test, hasil jawaban ditunjukkan pada Gambar 2.

Para mahasiswa baru lebih banyak menggunakan Google Classroom dan Zoom. Lalu pertanyaan kedua, terdapat 34 orang (89\%) yang menjawab aplikasi yang mereka pakai membantu pembelajaran masa kini. Tetapi terdapat 26 orang $(68 \%)$ belum mengetahui atau mendengar aplikasi Ms. Teams. Lalu terdapat 27 orang (71\%) tersebut mengetahui aplikasi Ms. Teams melalui kampus. Terakhir, terdapat 18 orang $(47 \%)$ yang menyatakan bahwa pembelajaran daring bisa dilakukan di mana saja dan kapan saja. 
1. Pada masa sekolah, aplikasi apa yang digunakan untuk melakukan pembelajaran daring? More Details

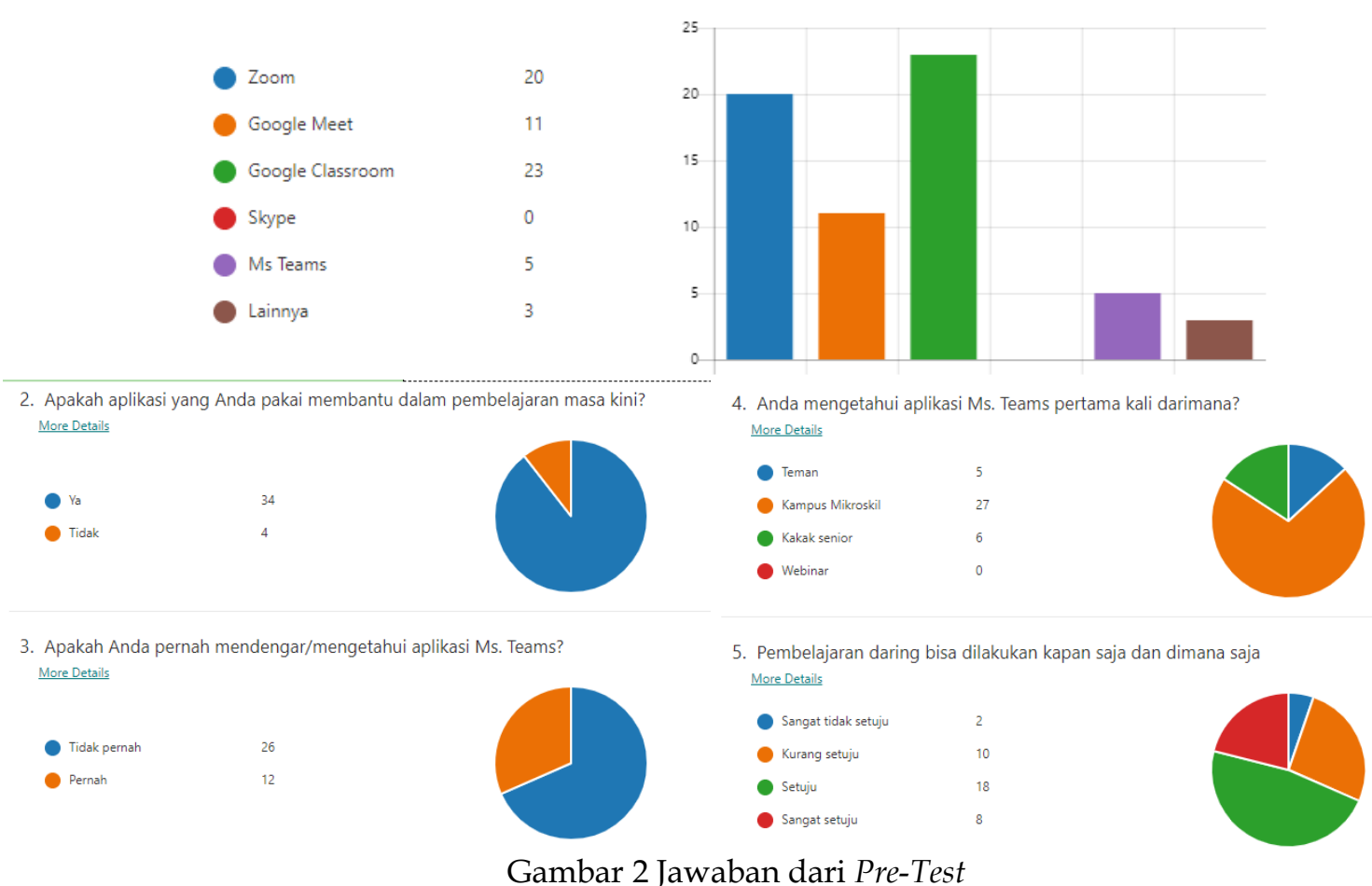

Setelah menyelesaikan pelatihan pertama, pelaksana mengirimkan soal kuis yang dijawab untuk mengetahui apakah mahasiswa memahami topik pelatihan pertama yang dibawakan. Soal kuis yang diberikan ditunjukkan pada gambar 3 .
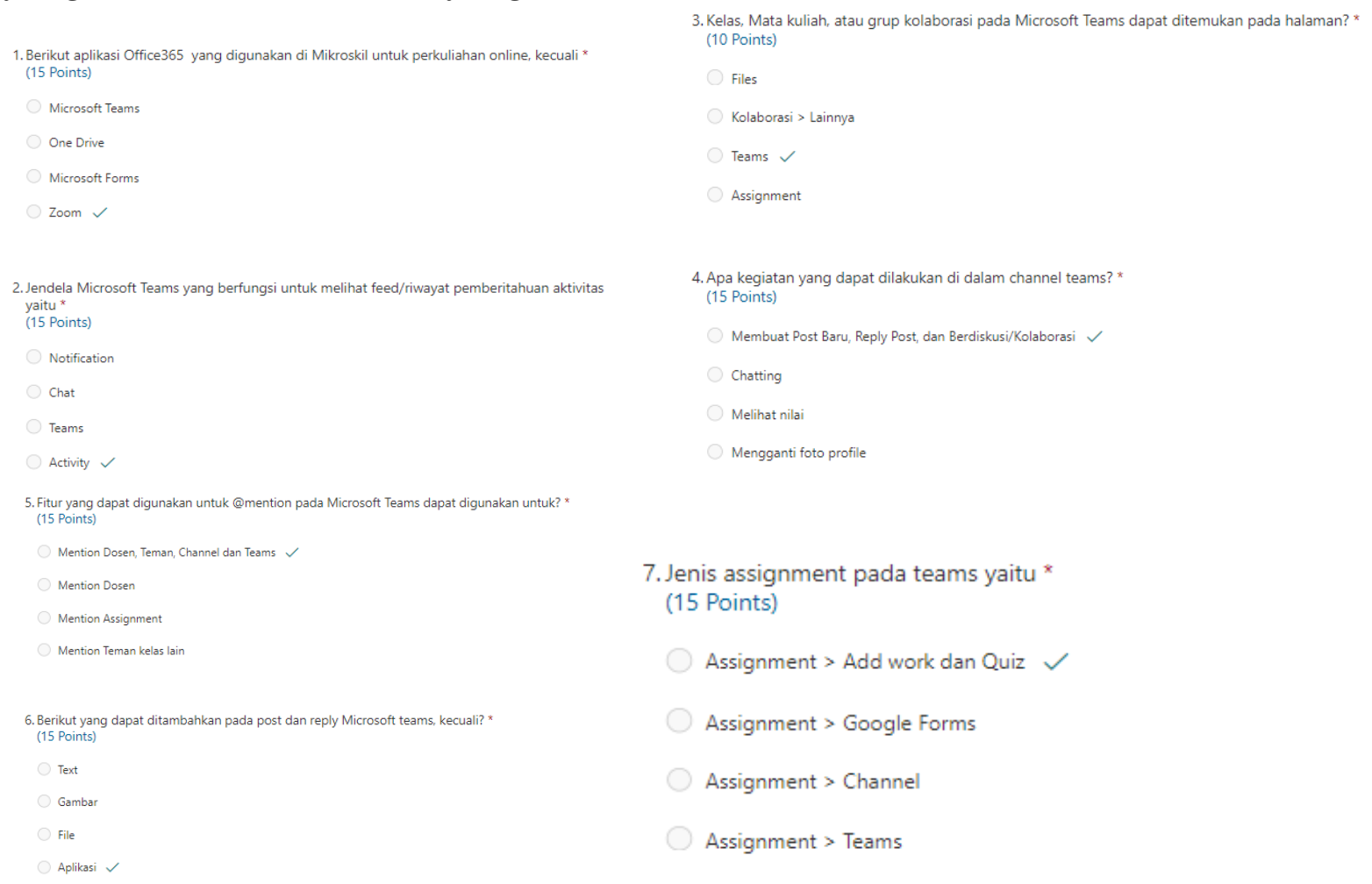

Gambar 3 Form Soal Kuis 
Setelah pemberian soal kuis untuk dijawab, terdapat 27 mahasiswa menjawab 7 soal kuis. Rekapan jawaban dari form soal kuis ditunjukkan pada Gambar 4.

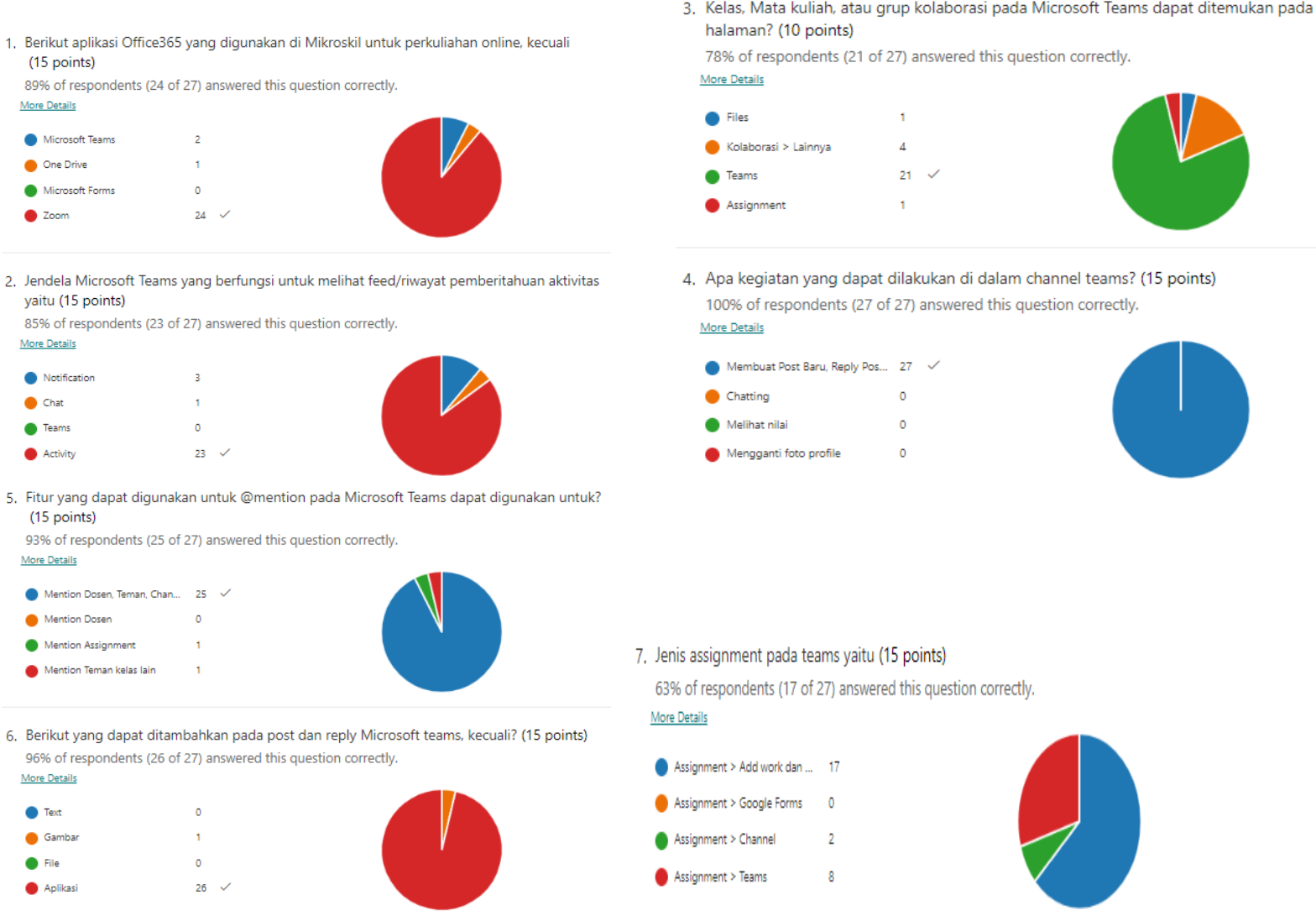

Gambar 4 Rekapan Jawaban Kuis

Rekapan jawaban form soal kuis yang ditunjukkan pada Gambar 4 menunjukkan bahwa rata - rata mahasiswa mengikuti dan menjawab dengan benar dari pelatihan pertama yang diajarkan oleh pelaksana. Dari 7 soal yang diberikan, jawaban benar berada di atas 60 persen. Hal itu menunjukkan bahwa mahasiswa baru yang mengikuti pelatihan ini paham dengan yang diajarkan dan disampaikan dari pelaksana.

Setelah melakukan pelatihan selama 2 (dua) hari, para mahasiswa diberikan form post-test. Pertanyaan post-test ditunjukkan pada Gambar 5 .

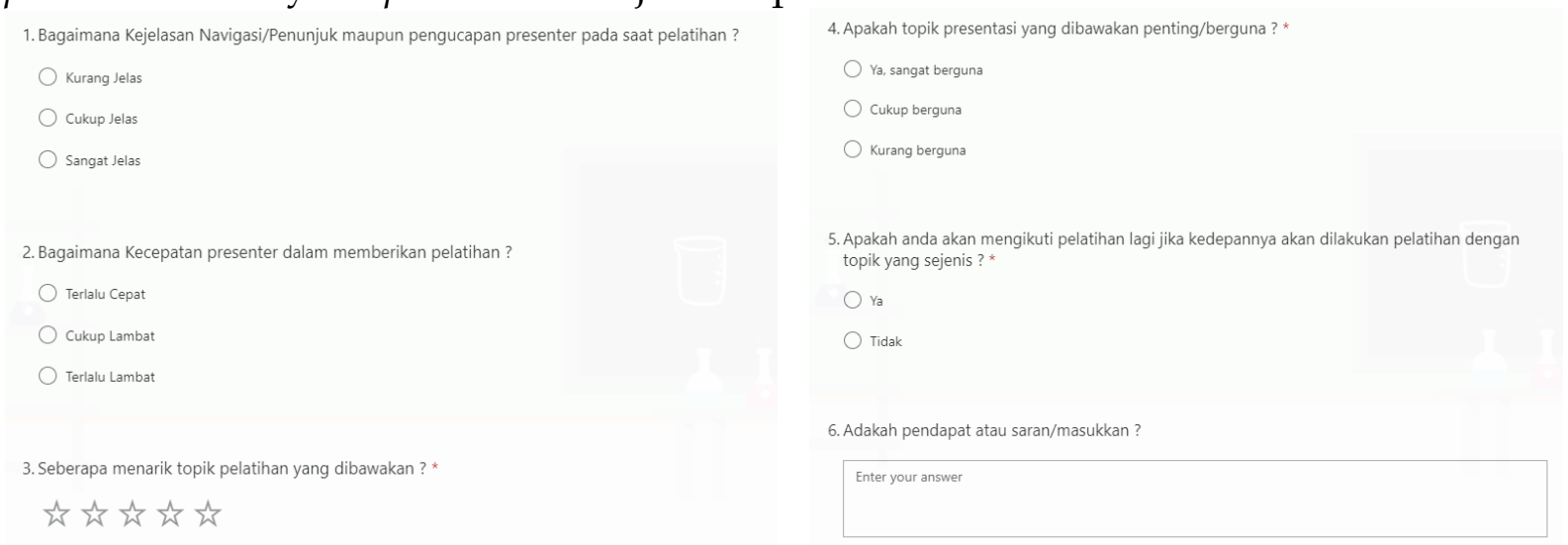

Gambar 5 Form post-test 
Pada form post-test, terdapat 6 (enam) soal yang diberikan kepada mahasiswa yang mengikuti pelatihan kedua. Soal yang diberikan pada form post-test:

a. Kejelasan penunjuk maupun pengucapan pelaksana pada sesi pelatihan

b. Kecepatan dari pelaksana dalam memberikan pelatihan

c. Sisi menarik pada topik pelatihan yang diajarkan

d. Pentingnya topik presentasi yang diajarkan

e. Mengikuti kembali pelatihan tersebut jika diselenggarakan kembali

f. Saran dan pendapat yang diberikan

Pada pelatihan kedua, terdapat 36 mahasiswa baru mengikuti pelatihan tersebut. Hasil jawaban post-test ditunjukkan pada Gambar 6:

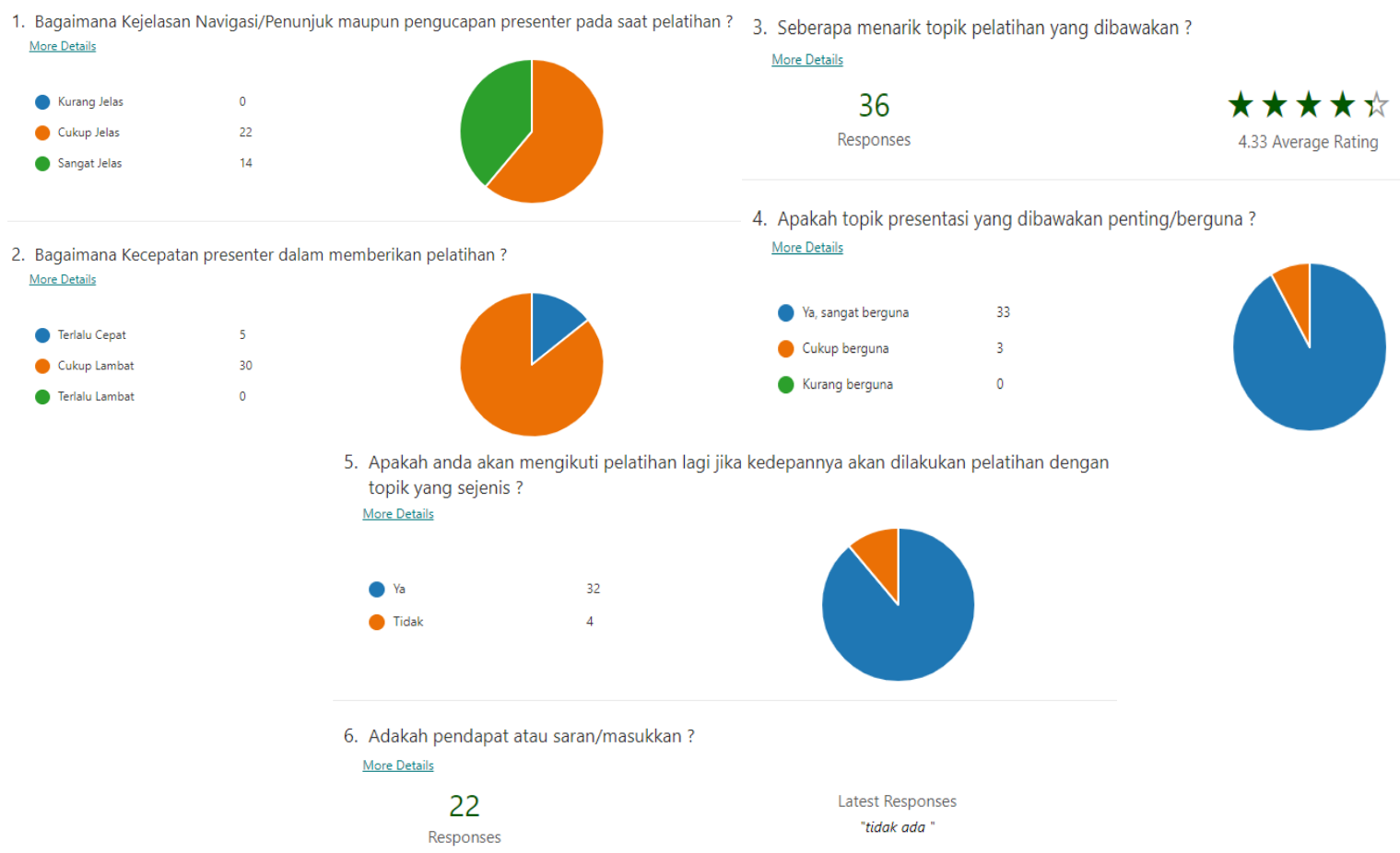

Gambar 6 Rekapan Hasil post-test

Dari hasil jawaban form post-test:

1. Pada pertanyaan pertama, terdapat 22 orang $(61 \%)$ menjawab bahwa penunjuk dan pengucapan pelaksana pada saat pelatihan cukup jelas disampaikan. 39\% lainnya (14 orang) menyebutkan penyampaian sangat jelas.

2. Pada pertanyaan kedua, terdapat 30 orang $(86 \%)$ menjawab bahwa pelaksana cukup lambat dalam memberikan pelatihan sehingga mahasiswa baru mudah mengerti apa yang disampaikan.

3. Pada pertanyaan ketiga, sebanyak rata-rata 4,33 mahasiswa baru memberikan penilaian seberapa menarik topik pelatihan yang dibawakan oleh pelaksana. Rincian penilaian mahasiswa baru untuk ketertarikan topik yang diberikan:

a. 18 orang memberikan nilai 5 untuk topik pelatihan yang dibawakan.

b. 14 orang memberikan nilai 4 untuk topik pelatihan yang dibawakan.

c. 2 orang memberikan nilai 3 untuk topik pelatihan yang dibawakan. 
d. 2 orang memberikan nilai 2 untuk topik pelatihan yang dibawakan.

Dari rincian tersebut, mahasiswa baru dominan tertarik dengan topik pelatihan yang dibawakan oleh pelaksana sehingga mahasiswa baru mengikuti secara menyeluruh.

4. Pada pertanyaan keempat, 33 orang $(92 \%)$ menyebutkan bahwa topik pelatihan yang diajarkan sangat penting/berguna. Mereka bisa mempraktekkan secara penuh karena topik pelatihan berisi informasi penting.

5. Pada pertanyaan kelima, 32 orang $(89 \%)$ menyebutkan bahwa ingin mengikuti kembali pelatihan dengan topik sejenis dikarenakan banyak informasi yang bisa ditelaah lebih banyak dan banyak fitur yang bisa diajarkan.

6. Pada pertanyaan keenam, pertanyaan tersebut bersifat opsional sehingga hanya 22 orang yang mengisi saran/masukkan kepada pelaksana. Saran yang diberikan lebih didominasi seperti keaktifan anggota pelaksana lebih ditingkatkan dan komunikasi antar dosen - mahasiswa juga kuat.

Hasil post-test yang dirincikan dan direkap menunjukkan bahwa mahasiswa baru yang mengikut pelatihan sudah memahami cara menggunakan Ms. Teams secara keseluruhan.

\section{Simpulan dan Rekomendasi}

Sebelum pelatihan berlangsung, mahasiswa baru sedikit dibingungkan dengan aplikasi Ms. Teams. Mereka hanya mengetahui nama aplikasi dan fungsi utama dari aplikasi tersebut yaitu untuk melakukan video meeting. Tetapi mereka tidak mengetahui banyak berbagai fungsi pada aplikasi Ms. Teams. Setelah terlaksananya 2 (dua) hari pelatihan, mahasiswa baru bisa menggunakan aplikasi Ms. Teams melalui desktop ataupun dengan mobile. Mahasiswa baru juga memahami dan mengetahui bahwa aplikasi Ms. Teams tidak hanya bisa melakukan video meeting, tetapi juga bisa berbagi dokumen, melakukan chat dengan teman ataupun dosen yang bersangkutan, serta bisa mengumpulkan tugas di aplikasi tersebut tanpa harus menggunakan aplikasi lainnya seperti Google Classroom.

Mahasiswa baru juga mendapat ilmu bahwa tidak serta merta kelas online hanya disuguhkan kuliah saja, tetapi mahasiswa baru juga bisa mengikuti kuis yang diberikan oleh dosen pengajar secara langsung. Hasil dari form pre-test dengan posttest beserta soal kuis menunjukkan mahasiswa antusias mengikuti pelatihan yang dilakukan dan menjawab soal kuis dengan benar dan tepat. Rekomendasi yang dapat diberikan adalah memberikan pelatihan yang lebih lanjut seperti mengajarkan penggunaan Ms. Office kepada mahasiswa baru pada saat perkuliahan sudah dimulai dan pengolahan data dari pre-test dan post-test. Pengabdian ini juga tidak menutup kemungkinan akan berlangsung kembali sebelum tahun ajaran baru dengan peserta yang berbeda. Selain peserta yang berbeda, materi yang dibawakan tidak akan sama dengan pengabdian yang sudah berlangsung. Jenis pertanyaan untuk pre-test dan post-test tentunya akan berbeda sehingga bisa dilakukan beberapa penelitian seperti penelitian deskriptif - kualitatif (Oktavian \& Aldya, 2020; Satrianingrum \& Prasetyo, 2020) ataupun metode penelitian kepustakaan (Dewi, 2020; Handarini \& Wulandari, 2020). 


\section{Daftar Pustaka}

Anaelka, A. H. (2018). Education 4.0 Made Simple: Ideas For Teaching. International Journal of Education and Literacy Studies, 6(3), 92. https://journals.aiac.org.au/index.php/IJELS/article/view/4616

Anderson, J. (2020). Should schools close when coronavirus cases are still rare? Quartz. https:// qz.com/1810224/does-closing-schools-protect-kids-and-us-fromcoronavirus/

Dewi, W. A. F. (2020). Dampak COVID-19 terhadap Implementasi Pembelajaran Daring di Sekolah Dasar. Edukatif : Jurnal Ilmu Pendidikan, 2(1), 55-61. https://doi.org/10.31004/edukatif.v2i1.89

Fitriyani, Y., Fauzi, I., \& Sari, M. Z. (2020). Motivasi Belajar Mahasiswa Pada Pembelajaran Daring Selama Pandemik Covid-19. Profesi Pendidikan Dasar, 7(1), 121-132. https://doi.org/10.23917/ppd.v7i1.10973

Handarini, O. I., \& Wulandari, S. S. (2020). Pembelajaran Daring Sebagai Upaya Study From Home (SFH). Jurnal Pendidikan Administrasi Perkantoran (JPAP), 8(3), 465-503.

Jamaluddin, D., Ratnasih, T., Gunawan, H., \& Paujiah, E. (2020). Pembelajaran Daring Masa Pandemik Covid-19 Pada Calon Guru : Hambatan, Solusi dan Proyeksi. Karya Tulis Ilmiah UIN Sunan Gunung Djjati Bandung, 1-10. http://digilib.uinsgd.ac.id/30518/

Oktavian, R., \& Aldya, R. F. (2020). Efektivitas Pembelajaran Daring Terintegrasi di Era Pendidikan 4.0. Didaktis: Jurnal Pendidikan Dan Ilmu Pengetahuan, 20(2), 129_ 135. https:// doi.org/10.30651/didaktis.v20i2.4763

Orgaz, F., Moral, S., \& Domínguez, C. (2018). Student's Attitude and Perception with the Use of Technology in the University. Journal of Educational Psychology Propositos y Representaciones, 6(2), 277-299.

Rigianti, H. A. (Universitas P. Y. I. (2020). Kendala Pembelajaran Daring Guru Sekolah Dasar Di Kabupaten Banjarnegara. Elementary School: Jurnal Pendidikan Dan Pembelajaran Ke-SD-An, 6. https://journal.upy.ac.id/index.php/es/article/view/768

Santika, I. W. E. (2020). Pendidikan Karakter pada Pembelajaran Daring. Indonesian Values and Character Education Journal, 3(1), 8-19.

Satrianingrum, A. P., \& Prasetyo, I. (2020). Persepsi Guru Dampak Pandemi Covid19 terhadap Pelaksanaan Pembelajaran Daring di PAUD. Jurnal Obsesi : Jurnal Pendidikan Anak Usia Dini, 5(1), 633. https://doi.org/10.31004/obsesi.v5i1.574

Sohrabi, C., Alsafi, Z., O'Neill, N., Khan, M., Kerwan, A., Al-Jabir, A., Iosifidis, C., \& Agha, R. (2020). World Health Organization declares global emergency: A review of the 2019 novel coronavirus (COVID-19). International Journal of Surgery, 76(February), 71-76. https:// doi.org/10.1016/j.ijsu.2020.02.034 
Syarifudin, A. S. (2020). Impelementasi Pembelajaran Daring Untuk Meningkatkan Mutu Pendidikan Sebagai Dampak Diterapkannya Social Distancing. Jurnal Pendidikan Bahasa Dan Sastra Indonesia Metalingua, 5(1), 31-34. https://doi.org/10.21107/metalingua.v5i1.7072

Traxler, J. (2018). Distance learning - Predictions and possibilities. Education Sciences, 8(1). https://doi.org/10.3390/educsci8010035

Wahyono, P., Husamah, H., \& Budi, A. S. (2020). Guru profesional di masa pandemi COVID-19: Review implementasi, tantangan, dan solusi pembelajaran daring. Jurnal Pendidikan Profesi Guru, 1(1), 51-65. http://ejournal.umm.ac.id/index.php/jppg/article/view/12462

Yang, J., Park, E. C., Lee, S. A., \& Lee, S. G. (2019). Associations Between Hand Hygiene Education and Self-Reported Hand-Washing Behaviors Among Korean Adults During MERS-CoV Outbreak. Health Education and Behavior, 46(1), 157-164. https://doi.org/10.1177/1090198118783829 